\title{
Hydrological Impact Assessment of Climate Change on Lake Tana's Water Balance, Ethiopia
}

\author{
Zemede Mulushewa Nigatu ${ }^{1,2}$, Tom Rientjes ${ }^{2}$, Alemseged Tamiru Haile ${ }^{3}$ \\ ${ }^{1}$ Hawassa University, WGFC-NR, Hawassa, Ethiopia \\ ${ }^{2}$ University of Twente, ITC, Enschede, The Netherlands \\ ${ }^{3}$ International Water Management Institute (IWMI), Addis Ababa, Ethiopia \\ Email: zmn.nigatu@gmail.com
}

Received 2 September 2015; accepted 12 March 2016; published 15 March 2016

Copyright (C) 2016 by authors and Scientific Research Publishing Inc.

This work is licensed under the Creative Commons Attribution International License (CC BY). http://creativecommons.org/licenses/by/4.0/

(c) (i) Open Access

\section{Abstract}

The aim of this study is to evaluate the hydrological impacts of climate change on the water balance of Lake Tana in Ethiopia. Impact assessments are by downscaled General Circulation Model (GCM) output and hydrological modeling. For A2 and B2 emission scenarios, precipitation, maximum and minimum temperature estimates from the HadCM3 GCM were used. GCM output was downscaled using the Statistical DownScaling Model (SDSM 4.2). Impact analyses were applied for three future time periods: early, mid and late 21st century. Over-lake evaporation is estimated by Hardgrave's method, and over-lake precipitation is estimated by inverse distance weighing interpolation, whereas inflows from gauged and ungauged catchments are simulated by the HBV hydrological model. Findings indicate increases in maximum and minimum temperature on annual base for both emission scenarios. The projection of mean annual over lake precipitation for both A2 and B2 emission scenarios shows increasing pattern for $21^{\text {st }}$ century in comparison to the baseline period. The increase of mean annual precipitation for $\mathrm{A2}$ emission scenario is $\mathbf{9 \%} \mathbf{1 1 2}$ $\mathrm{mm} /$ year $), 10 \%(125 \mathrm{~mm} /$ year $)$ and $11 \%(137 \mathrm{~mm} /$ year $)$ for the three future periods respectively. B2 emission scenario mean annual precipitation shows increase by $9 \%(111 \mathrm{~mm} /$ year), 10\% (122 $\mathrm{mm} /$ year) and $10 \%(130 \mathrm{~mm} /$ year $)$ respectively for the three future periods. Findings indicate consistent increases of lake storage for all three future periods for both A2 and B2 emission scenarios.

\section{Keywords}

Climate Change, Water Balance, SDSM, Statistical Downscaling, Lake Tana 


\section{Introduction}

There is a growing consensus that climate change is a reality. Changes are reported for nearly all climatic zones including humid equatorial zones but also seasonal arid tropical zones. Changes vary since climates are characterized by temporal and spatial unevenness [1] that, moreover, differs in extent. A number of studies report on climate change in the upper Blue Nile in Eastern Africa and address aspects of hydrological impacts.

For hydrological assessments for catchment systems of regional scale $\left(<1500 \mathrm{~km}^{2}\right)$, modelling results of General Circulation Model (GCM) are not directly applicable due to the coarse resolution of the GCM model grid elements that commonly is around $250 \mathrm{~km} \times 250 \mathrm{~km}$. Recently, [2] [3] studied climate change impact in Upper Blue Nile by direct use of GCM outputs ignoring aspects of the course scale resolution. It is described that hydrological impacts of climate change on the Lake Tana water balance are not well explored [2] [3]. Recently, by applying a perturbation downscaling approach of GCM outputs, [4] investigated the impact of climate change on high rainfall and flow extremes for the Nyando River and Lake Tana catchments in the Upper Blue Nile basin, Ethiopia. The result of their study indicated increases in temperature but did not indicate systematic increases or decreases of rainfall besides changes in inter-annual variability.

The general objective of this study is to evaluate hydrological impacts of climate change on the water balance of Lake Tana. This study assesses long-time series of in-situ measured precipitation (mostly rainfall), potential evaporation, maximum and minimum temperature for five stations for the period 1981-2010. GCM outputs for the A2 and B2 scenario are downscaled by SDSM 4.2 (see at http://www.sdsm.org.uk). We assess patterns of SDSM output for the baseline period (1981-2010) and make projections for the time periods 2010-2039, 20402069 and 2070-2099. By this approach, results from downscaling can directly be used in hydrological modelling to assess hydrological impacts on the water balance of Lake Tana.

In this study, climate change impact for Lake Tana basin area is assessed at monthly time step by using downscaled GSM outputs that serve as input to hydrological models. We simulate the lake water balance for all three time periods and assess the pattern of hydrological alteration by summing model-simulated stream-flow from gauged and ungauged catchments, and by estimating over-lake precipitation and lake evaporation. In the approach, the stream flow from ungauged catchments is estimated by the HBV (Hydrologiska Byrans Vattenbalansavdelning) hydrological model [5] using model parameters by a regionalization study in the Lake Tana basin [6]. For the baseline period as well as the three future time periods windows the same HBV model parameters are applied that as such remain unchanged.

\section{Study Area and Data}

Lake Tana occupies a wide depression in the Ethiopian plateau that covers an area of $3156 \mathrm{~km}^{2}$ in area. It is the third largest Lake in the Nile Basin and largest lake in Ethiopia. It is approximately $84 \mathrm{~km}$ long and $66 \mathrm{~km}$ wide. The water balance of the lake accounts all inflows and outflows in a given period. The term inflow refers to lake precipitation and surface runoff from gauged and ungauged catchments to the lake. Outflow refers to evaporation and stream flow through the Blue Nile (Abay) River. Based on [7] the lake inflow is $1254 \mathrm{~mm} /$ year from gauged catchments, $527 \mathrm{~mm} /$ year from ungauged catchments and $1347 \mathrm{~mm} /$ year from lake areal precipitation. Lake evaporation was estimated at $1563 \mathrm{~mm} /$ year whereas river outflow was estimated at $1480 \mathrm{~mm} /$ year with an overall lake water balance error of $85 \mathrm{~mm} /$ year. [8] suggests that Lake Tana historical water level variations are related to reduction in dry season flows attributed to human and climate-induced changes.

Daily records of five meteorological stations and hydrological data were collected for Adet, Bahir Dar, Dangila, Debre Tabor and Gondar stations (see Figure 1) for the period of 1981-2010. Missing rainfall data was estimated by using the rainfall data at neighboring stations. Missing daily precipitation was estimated by using arithmetic mean and normal ratio method based on the procedure proposed by [9]. Consistency of time series data is analyzed based on double mass curve analysis. In such analysis a plot of two cumulative quantities that are measured for the same time period should be consistent with their proportionality remain unchanged as indicated by the slope line (modified after [9]).

\section{Methodology}

The HadCM3 output for the A2a and B2a emission scenarios were statistically downscaled using the Statistical DownScaling Model (SDSM) [10]. The downscaled climate variables are maximum and minimum temperature 


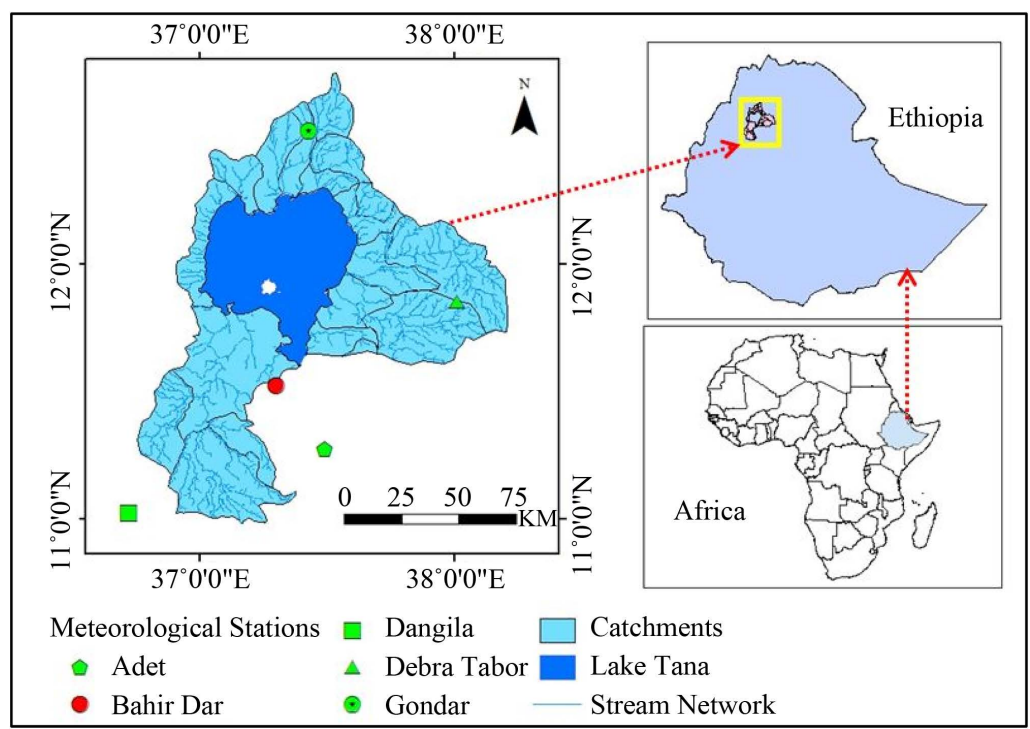

Figure 1. Lake Tana sub-basin with respective gauged catchments and meteorological stations.

and precipitation together with an estimated potential evaporation. The downscaled SDSM outputs were used as input for the HBV hydrological model to assess climate change impact on the water balance of Lake Tana for future time periods.

\subsection{Statistical Downscaling}

SDSM (version 4.2) was downloaded freely from http://www.sdsm.org.uk. It establishes statistical relationships between output from GCM at large-scale (i.e. predictors) and observed data from local meteorological stations at point scale (i.e. predictands) based on multiple linear regression techniques. The predictor variables of HadCM3 are available at grid element (i.e. box) basis and are freely downloadable from [11] at http://www.cics.uvic.ca/scenarios/sdsm/select.cgi. Daily maximum temperature, minimum temperature and precipitation were downscaled following the procedure described in the section below that is adapted from the SDSM 4.2 manual [10].

Predictand data quality control: Data collected from meteorological stations may not be $100 \%$ complete or be accurate. In SDSM, quality control of time series data is a crucial step to handle missing or imperfect data. For all meteorological stations, the quality of daily time series was checked to identify and to correct missing and suspected values. Quality control also is applied for identifying possible outliers of predictands before screening of the predictor variables.

Screening downscaling predictors: Its main purpose is to assist the user in the selection of appropriate downscaling predictor variables. In [12] selection of predictors in SDSM is described that is an iterative process and partly based on subjective judgment of the user's.

In this study, predictors with relatively high partial correlation value, and a P-value less than 0.05 are selected. According to [13], partial correlation is defined as "the correlation between two variables after removing the linear effect of the third or more other variables". It is calculated using Equation (1) that shows that the partial correlation between variable $j$ and $i$ controls the third variable $k$ where $R_{i j}$ is correlation coefficient between $\mathrm{j}$ and i:

$$
R_{i j, \mathrm{k}}=\frac{R_{i j}-R_{i k} R_{j k}}{\sqrt{\left(1-R_{i k}^{2}\right)\left(1-R_{j k}^{2}\right)}}
$$

According to [14] the p-value is estimated by transforming the correlation " $R$ " to establish a t-statistic with $n$ -2 degrees of freedom (see Equation (2) below) and is used to eliminate any one of the predictors in partial correlation method with the n number of observations. 


$$
t=\frac{R}{\sqrt{\frac{1-R^{2}}{n-2}}}
$$

A statistical test (i.e. t-test) is used to calculate the P-value, which is used to accept or to reject the hypotheses that the two sets of data (i.e. observed and simulated) could have similar, or the same, statistical properties. Significant differences between the simulated and observed climate data may arise from errors in the observed data, by model smoothing of the observed data or by random error.

High partial correlation values show strong association between predictor and predictand whereas small Pvalues indicate that the occurrence of this association is less likely by chance. The partial correlation statistics and P-values show the strength of the association between predictor and predictand.

SDSM model calibration: By calibrating the SDSM, the downscaling model is build based on multiple linear regression equations between daily predictand data (i.e., meteorological station data) and GCM predictor variables (i.e., GCM model outputs) (e.g. [15]). In this study calibration is done by using selected Screen Variables and level of the variance in the local predictand of daily precipitation, maximum and minimum temperature of Gondar, Bahir Dar, Debra Tabor, Aykel, Dangila and Adet stations data for the period 1981-2010. This 30 year period has served as the baseline period for this study.

During model calibration, stepwise regression was applied for precipitation. For maximum and minimum temperature, that in the approach was considered an unconditional process, the same regression technique was applied. In stepwise regression, initially all predictors are included during predictor screening whereas during the analysis the least significant terms are removed at every step. For unconditional processes, a direct link is assumed between the predictors and predictand. For each station, the model calibration result is checked by visual inspection (i.e. frequency analysis output graphs of the model output versus the observed) and statistical methods (i.e. statistical summary of model output versus observed) to evaluate the skill of the model to reproduce the scenario data.

According to [12] the calibration result of SDSM is exhibited with percentages of explained variance (see Equation (3) below). The percentage of the explained variance ( $\% \mathrm{ev}$ ) reads [16]:

$$
\% e v=\frac{\sum_{i=1}^{n}\left(S_{i}-\bar{O}\right)}{\sum_{i=1}^{n}\left(O_{i}-\bar{O}\right)} \times 100
$$

where $S_{i}$ is the simulated value for day $i, O_{i}$ is the observed value at day $i, \bar{O}$ is the mean of the observations for the period and $n$ is the number of days of the period of SDSM model run and the observed data. The percentage of explained variance is used to describe the variations of the simulated data with respect to the mean of the observations. It shows the extent to which the regional predictors determine the daily variations of local predictands.

Scenario generation: The Scenario Generation process produces daily base data for maximum temperature, minimum temperature and precipitation for the entire period 1981-2099 including the future time periods. Each predictand is generated based on the calibration result and the daily atmospheric predictors of the HadCM3. The calibration result is used based on assumption that predictor-predictand relationships under the current condition remain valid under future climate conditions too.

For each emission scenario (B2 and A2), twenty ensembles of synthetic daily time series data were produced for 139 years. The stochastic component of SDSM allows the generation of up to 100 ensembles, with ensemble data that have the same statistical characteristics but vary on a day-to-day basis. Selection of only twenty ensembles is performed with a fair match between observed and simulated daily temperature and precipitation. The twenty ensemble outputs are averaged for consistency and robustness to improve the performance of model for the future time periods. The method was applied for three future time periods 2010-2039 (2020s), 2040-2069 (2050s) and 2070-2099 (2080s) and for the A2 and B2 emission scenarios. Precipitation, maximum and minimum temperature outputs were generated.

\subsection{Over-Lake Precipitation and Evaporation}

Over-lake daily precipitation for the period 1980-2010 was estimated by inverse distance weighting interpolation [17]. Four stations that are located close to the lake and one station on an island in the lake were selected. 
As indicated in [18], a weight power of 2 represents best spatial variability at daily time step. With increasing distance from a station from the interpolation point, the weight function approaches zero. The station weight functions are normalized and their sum is equal to one.

Since only little meteorological time series data is available, evaporation for the baseline period 1981-2010 and future time horizons (2011-2099) is calculated by Hargreave's method [19] (see Equation (4)).

$$
E_{r c}=0.0022 * R_{a} * \delta^{\prime} T^{0.5} *(T+17.8)
$$

where: $R_{a}$ is mean extra-terrestrial radiation $\left[\mathrm{MJ} \cdot \mathrm{m}^{-2} \cdot \mathrm{d}^{-1}\right]$, which is a function of the latitude $f, \delta^{\prime} T$ is temperature difference (i.e. mean monthly maximum temperature minus mean monthly minimum temperature for the month of interest $\left[{ }^{\circ} \mathrm{C}\right]$ ) and $T$ is mean air temperature $\left[{ }^{\circ} \mathrm{C}\right]$. Maximum and minimum temperature used for future time periods were from SDSM. Hargreave's method is selected by a wide consensus that the method gives reasonable estimates of evaporation despite its low demand for input data.

\subsection{Hydrological Impacts of Climate Change Modeling}

For hydrological impact assessment the HBV-96 model [5] was selected. Calibration (1994-2000) and validation (2001-2003) of the MATLAB coded model for all gauged and ungauged catchments is shown in [6]. The model consists of subroutines for estimating actual evaporation, for soil moisture accounting and for runoff generation. Its flexible structure allows creating sub-divisions with respect to sub-basins and climatic zone makes it suitable for this study. It is possible to run, calibrate and validate the model separately for several sub-basins [20] and to simulate runoff from the entire sub-basins.

The analysis of water balance is carried out at daily base for all three time horizons in future period each covering a non-overlapping 30-year period that are the 2020s (2011-2040), 2050s (2041-2070) and 2080s (20712100). The lake water balance equation used in this study reads:

$$
\frac{\Delta S}{\Delta t}=P+Q_{\text {gauged }}+Q_{\text {ungauged }}-E-Q_{\text {out }}
$$

where $\Delta S / \Delta t$ is the change in storage over time [ $\mathrm{Mm}^{3} /$ day]. $P$ is over-lake precipitation [ $\mathrm{Mm}^{3} /$ day]. $E$ is open water evaporation $\left[\mathrm{mm}^{3} /\right.$ day]. $Q_{\text {gauged }}$ is gauged catchments inflow $\left[\mathrm{Mm}^{3} /\right.$ day $] . Q_{\text {ungauged }}$ is the ungauged catchments inflow $\left[\mathrm{Mm}^{3} /\right.$ day $]$ and $Q_{\text {out }}$ is the Blue Nile River outflow $\left[\mathrm{Mm}^{3} /\right.$ day $]$.

\section{Results and Discussion}

Selected predictors from National Centers for Environmental Prediction (NCEP) data are chosen to calibrate the SDSM model. Screening was done based on partial correlation and P-value. The percentage of explained variance is higher for temperature than precipitation since temperature is spatially more homogeneous than precipitation [21]. The calibration result at Debre Tabor station is $81 \%$ for maximum temperature and $71 \%$ for minimum temperature. The percentage of explained variance of precipitation was calculated at Debre Tabor (35\%), Dangila (29\%), Dangila (29\%), Bahir Dar (21\%), Gondar (19\%) and Adet (17\%).

Here the term "anomaly" is used to refer to a devation of future climate condition from a baseline (1981-2010) climate condition. In this study the baseline period climatic condition is analysed based on meteorological station records of the study area. Positive anomaly indicates an increase from the baseline period, whereas a negative anomaly indicates a decrease from the baselin period. Projected changes in monthly rainfall statistics are vital means of evaluating the characteristics of rainfall at the study site. Figure 2 shows the general pattern of the monthly rainfall anomalies at Bahir Dar station. The A2 and B2 scenario noted an overall increasing pattern in the monthly precipitation particularly in August-November $(28-60 \mathrm{~mm})$ for all future windows and AprilMay $(4.7-8.7 \mathrm{~mm}$ ) in 2020s, whereras a consistent decreasing pattern is shown for the months of June-July (25 - $50 \mathrm{~mm}$ ) for all future periods. For the months of December-March no notable change was observed for the future periods. The anomaly was near zero for the remaining months indicating that future monthly rainfall amounts are close to that of the baseline period.

The projection of mean annual precipitation of lake catchments for both A2 and B2 emission scenarios shows increasing pattern for $21^{\text {st }}$ century in comparison to the baseline period. The increase of mean annual precipitation for A2 emission scenario is 29\% (397 mm/year), 34\% (470 mm/year) and 37\% (513 mm/year) respectively for the three future periods. B2 emission scenario mean annual precipitaion shows increases by $27 \%$ (371 


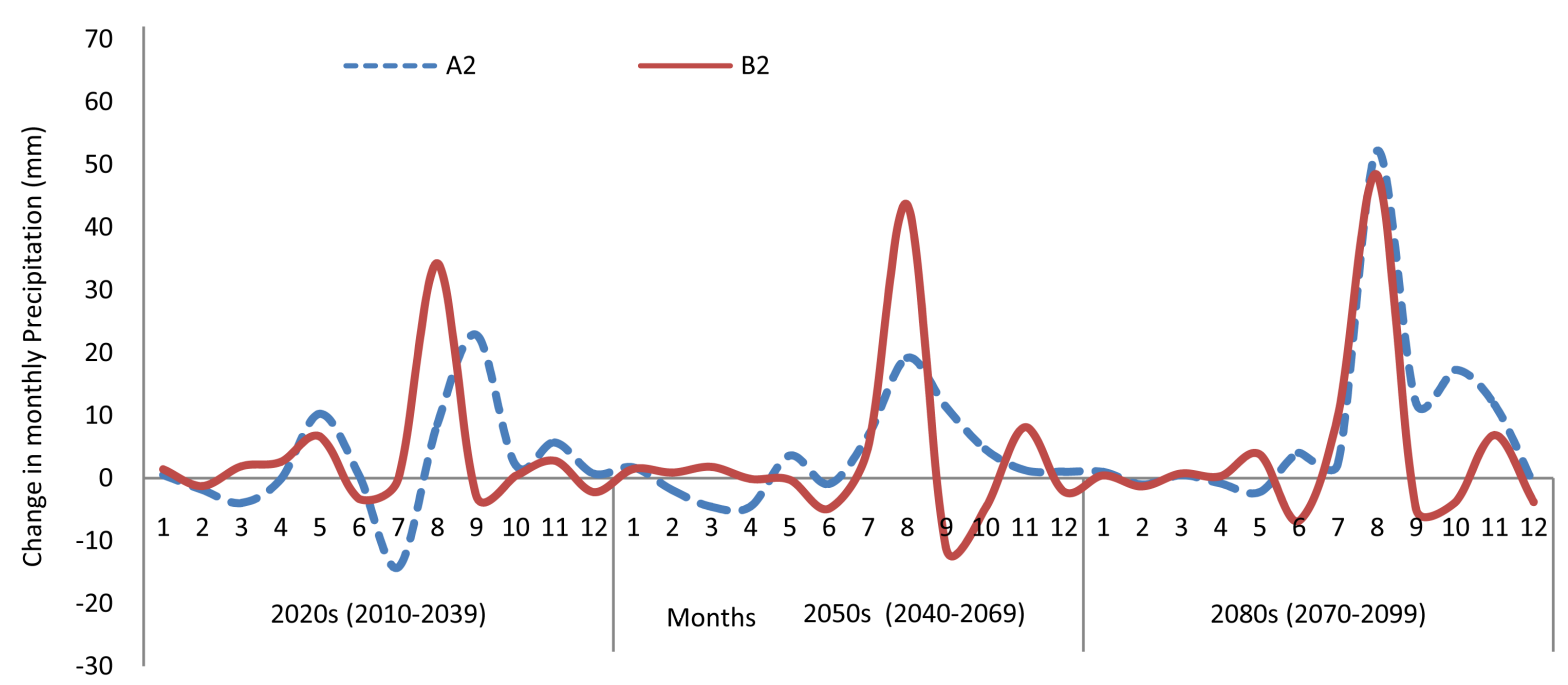

Figure 2. Projected monthly precipitation changes at Bahir Dar station.

$\mathrm{mm} /$ year), 32\% (447 mm/year) and 36\% (499 mm/year) respectively for the three future periods.

Similarlarly, downscaled results of precipitation [22] in the Upper Blue Nile basin indicate an overall increasing trend during the three future periods in the study area.Their study indicated that precipitation increases of $40 \%, 20 \%$ and $16 \%$ relative to the baseline period for HadCM3 A2 emissions scenario over the entire Nile basin for the three future periods.

Figure 3 shows the changes in mean monthly maximum temperature A2 and B2 scenarios for future periods. The $\mathrm{A} 2$ scenario shows increases of $+0.1^{\circ} \mathrm{C}$ to $+0.4^{\circ} \mathrm{C}$ for $2020 \mathrm{~s},+0.3^{\circ} \mathrm{C}$ to $+1.5^{\circ} \mathrm{C}$ at $2050 \mathrm{~s}$ and $+1.6^{\circ} \mathrm{C}$ to $+3.0^{\circ} \mathrm{C}$ for 2080s. The $\mathrm{B} 2$ scenario shows a pattern with increases from $+0.1^{\circ} \mathrm{C}$ to $0.5^{\circ} \mathrm{C}$ for $2020 \mathrm{~s},+0.7^{\circ} \mathrm{C}$ to $+1.3^{\circ} \mathrm{C}$ at 2050s and $+0.8^{\circ} \mathrm{C}$ to $+2.3^{\circ} \mathrm{C}$ for the end of $21^{\text {st }}$ century. The B2 scenario shows a pattern comparable for the A2 emission scenario for the first half of the $21^{\text {st }}$ century, but with large differences in temperature changes from the 2050s period, and onwards. In general both scenarios A2 and B2 show an increasing pattern of mean monthly maximum temperature.

Figure 4 shows the change anomalies in mean monthly minimum temperature of A2 and B2 scenarios for future periods. Both $\mathrm{A} 2$ and $\mathrm{B} 2$ scenarios noted consistent increases. The A2 scenario showed increases of $+0.1^{\circ} \mathrm{C}$ to $+1.1^{\circ} \mathrm{C}$ for $2020 \mathrm{~s},+0.1^{\circ} \mathrm{C}$ to $+2.3^{\circ} \mathrm{C}$ for $2050 \mathrm{~s}$ and $+0.8^{\circ} \mathrm{C}$ to $+3.9^{\circ} \mathrm{C}$ for 2080s. B2 scenario shows increases from $+0.1^{\circ} \mathrm{C}$ to $+0.8^{\circ} \mathrm{C}$ for $2020 \mathrm{~s},+0.9^{\circ} \mathrm{C}$ to $+1.7^{\circ} \mathrm{C}$ for 2050 s and $+0.1^{\circ} \mathrm{C}$ to $2.7^{\circ} \mathrm{C}$ by the end of the $21^{\text {st }}$ century. In general both scenarios noted increasing pattern of mean monthly minimum temperature.

Similarly, according to [23] globally there will likely be a temperature increase of $2^{\circ} \mathrm{C}$ by 2100 . IPCC [24] projection indicates that global temperatures will increase by $1^{\circ} \mathrm{C}$ to $3^{\circ} \mathrm{C}$ during the mid-twenty first century and about $2^{\circ} \mathrm{C}$ to $5^{\circ} \mathrm{C}$ during the late twenty first century.

\subsection{Lake Water Balance Components}

Lake evaporation: Annual mean lake evaporation is projected to be $2097 \mathrm{~mm}, 2107 \mathrm{~mm}$ and $2120 \mathrm{~mm}$ at the 2020s, 2050s and 2080s, respectively. For the A2 scenario, its increament ranges from 9\% (lowest at 2020s) to $11 \%$ (highest at end of $21^{\text {st }}$ century). Overall, an increase of mean annual lake evaporation is indicated with reference to the base line eperiod.

The increase of annual mean lake evaporation for the B2 scenario of the three future windows ranges from 9\% (lowest at 2020s) to $10 \%$ (highest at 2050s and end of $21^{\text {st }}$ century). It shows overall increasing pattern when compared to the base line period and distinct inter-annual variability in the model outputs. In general the increase of lake evaporation is due to increase of maximum and minimum temprature for all three scenarios.

Over-lake precipitation: Over-lake precipitation is one of the major components of the lake water balance. Here, it is estimated based on the inverse distance weighting interpolation using five stations which are situated in the surrounding of the lake. For the A2 emission scenario, annual over-lake precipitation ishigher than the baseline mean annual lake precipitation by $1 \%-6 \%, 1 \%-5 \%$ and $1 \%-7 \%$ for the 2020 s, 2050 s and 2080 s, 


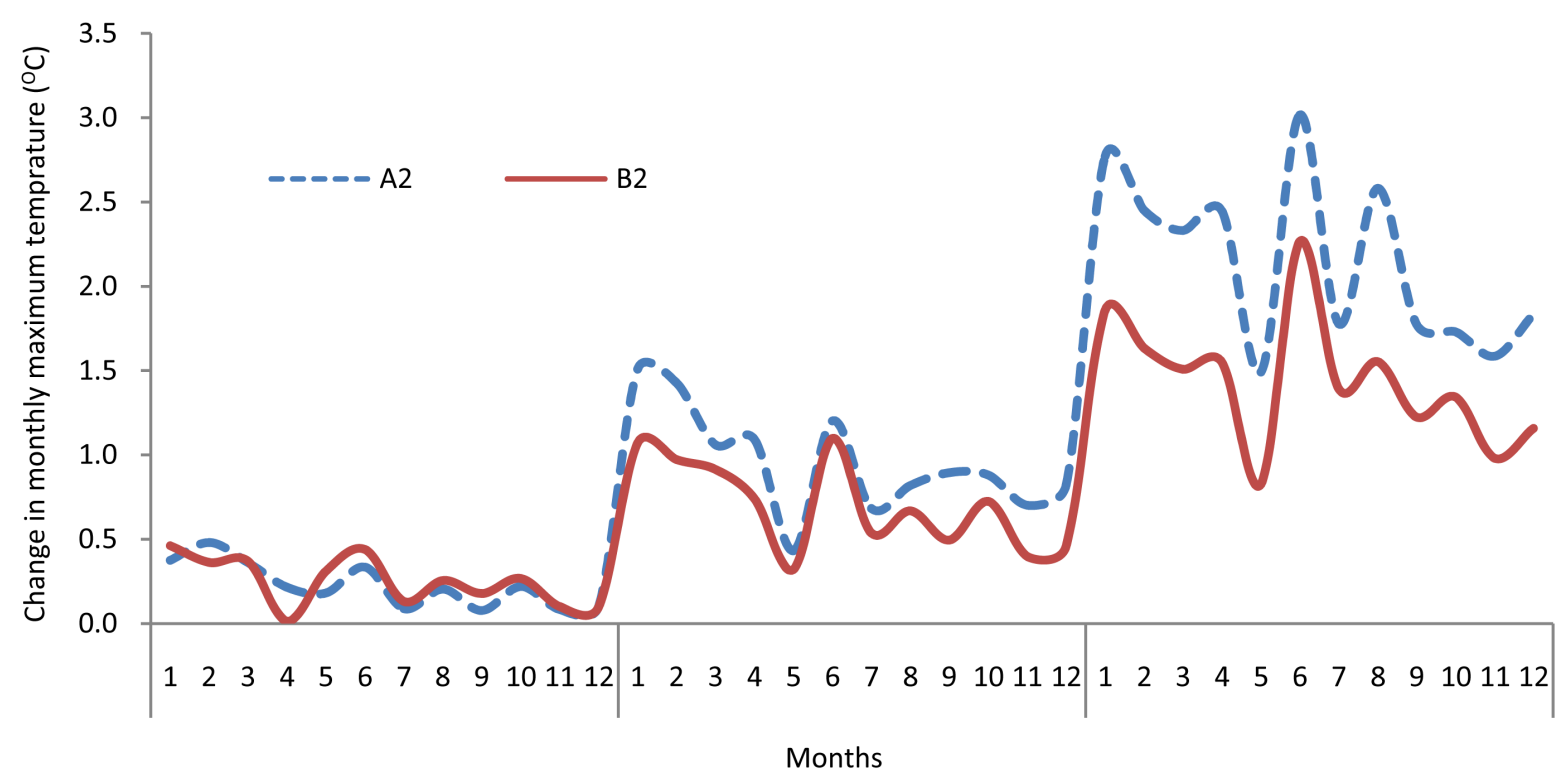

Figure 3. Change in monthly maximum temperature at Bahir Dar station.

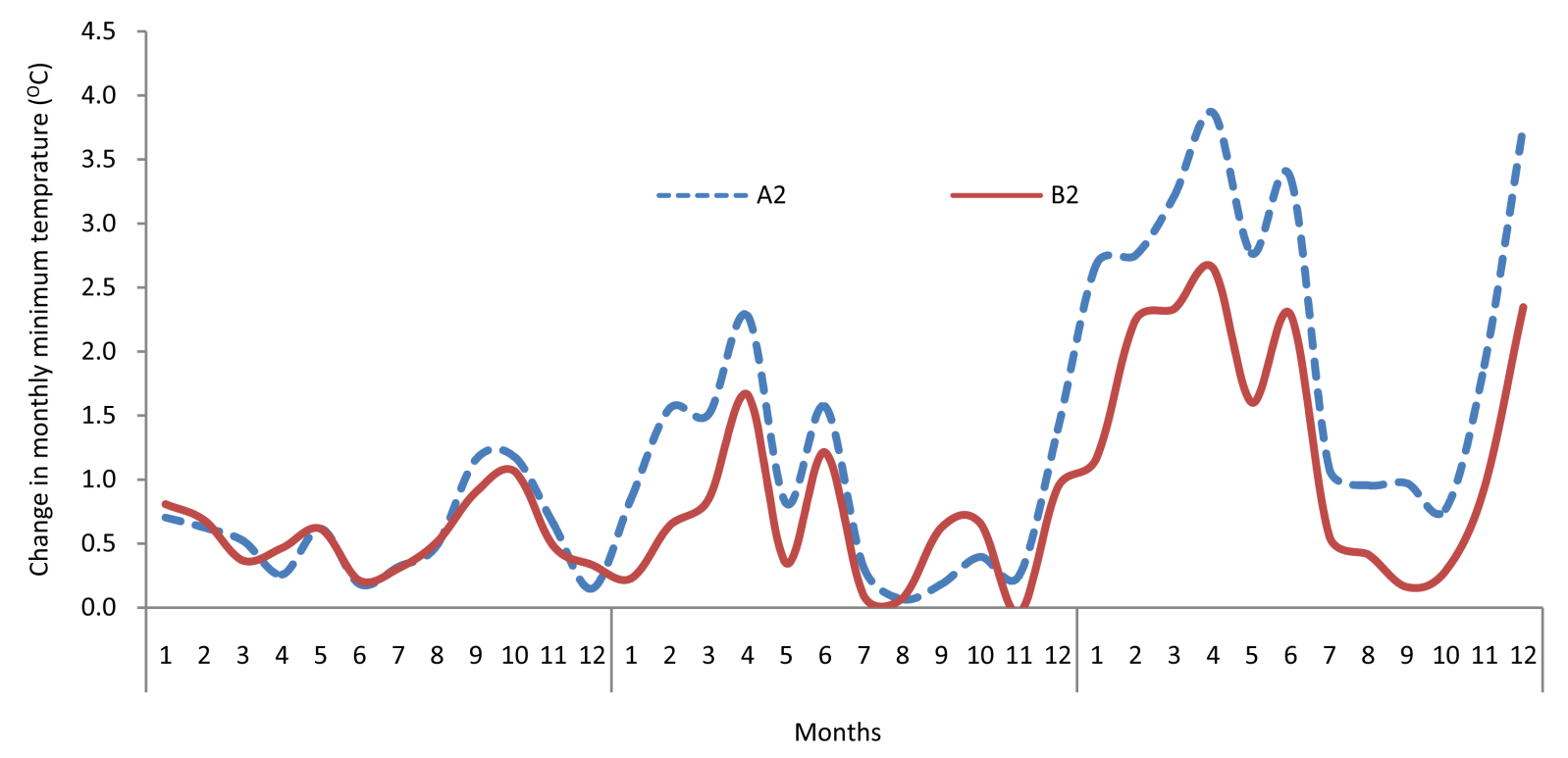

Figure 4. Change in monthly minimum temperature at Bahir Dar station.

respectively. For the B2 emission scenario, over lake precipitation projection shows increase of by $1 \%-4.2 \%$, $1 \%-4 \%$ and $1 \%-8.4 \%$ for respective future windows in comparison to the baseline period.

\subsection{Inflows from Gauged and Ungauged Catchments}

The total inflow to the lake is estimated from gauged and ungauged catchments by summing the inflows from all catchments. The inflow from each catchment is simulated by usingthe downscalled SDSM data (i.e. daily precipitation, mean temperature and evaporation) for runoff modelling.

Model parameters from ungauged catchments draining to Lake Tana were determined by a regionalization approach. Statistical characteristics of physical catchments characteristics served as input for multiple linear regression equationsfor parameterisation of the HBV model for each gauged catchment. The same physical catchments characteristics from ungauged catchments served to estimate model parameters of ungauged catch- 
ments. Full details of the regionalization approach are available in [6].

\subsection{Gauged Catchments Surface Water Inflow}

The projection of A2 emission scenario for estimation of mean annual lake inflow from gauged catchments for each future time period shows high inter-annual variablity characteristics. The projected A2 scenario for annual surface water inflow shows a consistant increas for all future time horizons. In general, the A2 scenario shows increases of annual surface water inflow of $17 \%-23 \%, 18 \%-28 \%$ and $19 \%-28 \%$ for the 2020 s, 2050 s and 2080s, respectively.

For the B2 scenario, projections show that annual surface water inflow consistently increases in all future time periods. In more detail, the B2 scenario shows increases of annual surface water inflow by $11 \%-24 \%, 12 \%-28 \%$ and $10 \%-31 \%$ for the 2020s, 2050s and 2080s, respectively.

\subsection{Ungauged Catchments Surface Water Inflow}

In general, both the A2 and B2 based estimation of surface water inflows from ungauged catchments shows a generally increasing pattern for all future time periods.

For the A2 scenario, projections of annual surface water inflow from unguaged catchments indicate a consistant increase for all future time periods. In particular, for the A2 scenario, annual surface water inflow from ungauged catchments increasesby 5\% - 26\%, $12 \%-30 \%$ and $14 \%-28 \%$ for the 2020 s, 2050s and 2080s periods, respectively.

For the B2 scenario, projected annual surafce water inflows from unguaged catchments also suggests a consistant increase in all future time horizons. In more detail, the B2 scenario based annual surface water inflow from ungauged catchments yielded increases of $9 \%-25 \%, 9 \%-25 \%$ and $9 \%-32 \%$ for the 2020 s, 2050s and 2080s, respectively.

\subsection{Projected Lake Water Balance Analysis}

Table 1 shows the summary of the water balance components with projected percentage changes. The water balance is estimated based on the inflow and outflow of Lake Tana, and lake evaporation.

In this study, lake water balance is established for the baseline period (1981-2010) and the three future time periods (2020s, 2050s and 2080s). The sum of the inflow from nine gauged and ten ungauged catchments was used to estimate the total stream flow into the lake. Stream flow for the future time periods is simulated by the HBV model using the downscaled rainfall, mean temperature, reference evaporation and model parameters by a regionalization study [6].

Table 1. Water balance components (mm/year) with expected percentage changes (\%).

\begin{tabular}{|c|c|c|c|c|c|}
\hline LWB components & Baseline & Scenarios & 2020s & 2050s & $2080 s$ \\
\hline \multirow{2}{*}{$\begin{array}{c}\text { Gauge catchment } \\
\text { Surface water inflow }\end{array}$} & \multirow{2}{*}{1253} & $\mathrm{~A} 2$ & $1524(+22 \%)$ & $1558(+24 \%)$ & $1588(+27 \%)$ \\
\hline & & B2 & $1531(+22 \%)$ & $1550(+24 \%)$ & $1566(+25 \%)$ \\
\hline \multirow{2}{*}{$\begin{array}{l}\text { Ungauged catchments } \\
\text { Surface water inflows }\end{array}$} & \multirow{2}{*}{933} & A2 & $1056(+13 \%)$ & $1077(+15 \%)$ & $1108(+19 \%)$ \\
\hline & & B2 & 1057 (+13\%) & $1072(+15 \%)$ & $1206(+29 \%)$ \\
\hline \multirow{2}{*}{$\begin{array}{l}\text { Over-lake } \\
\text { Rainfall }\end{array}$} & \multirow{2}{*}{1274} & $\mathrm{~A} 2$ & 1386 (+9\%) & $1399(+10 \%)$ & $1411(+11 \%)$ \\
\hline & & B2 & 1385 (+9\%) & $1396(+10 \%)$ & $1404(+10 \%)$ \\
\hline \multirow{2}{*}{$\begin{array}{c}\text { Over-lake } \\
\text { Evaporation }\end{array}$} & \multirow{2}{*}{2041} & A2 & 2097 (+3\%) & 2107 (+3\%) & $2120(+4 \%)$ \\
\hline & & B2 & $2098(+3 \%)$ & 2107 (+3\%) & $2118(+4 \%)$ \\
\hline Lake outflow (BNR) & 1520 & & $1520(0 \%)$ & $1520(0 \%)$ & $1520(0 \%)$ \\
\hline \multirow{2}{*}{ Storage change } & \multirow{2}{*}{-101} & A2 & +349 & +407 & +467 \\
\hline & & B2 & +355 & +390 & +537 \\
\hline
\end{tabular}

Values in $(+)$ indicates increase of change in percentage. LWB stands for Lake Water Balance. 


\section{Conclusions and Recommendations}

Understanding the water balance components of Lake Tana is vital to develop sound management plans in current and future time periods under changing climatic conditions. In this study hydrological impact of climate change on all water balance components of Lake Tana was evaluated for A2 and B2 emission scenarios. The Statistical Downscaling Model (SDSM 4.2 version) was used to downscale large-scale climatic variables using predictors obtained from the HadCM3 for both A2 and B2 scenario. Hydrological model (HBV) and optimized model parameter for gauged and ungauged catchment by a regionalization approach in [6] was used to simulate surface water inflow.

Projections on climate change in this study indicate that minimum and maximum temperature will increase thus effecting evapotranspiration and lake evaporation. The projection of mean annual precipitation for both A2 and B2 emission scenarios shows increasing pattern for $21^{\text {st }}$ century in comparison to the baseline period. The increased mean annual precipitation for A2 emission scenario is 9\% (112 mm/year), 10\% (125 mm/year) and 11\% (137 mm/year) for the three respective future windows. B2 emission scenario mean annual precipitaion increases by $9 \%$ (111 mm/year), 10\% (122 mm/year) and 10\% (130 mm/year) respectively for the three future windows. Consequently, increase of rainfall boosts increase of inflow both from gauged and ungauged catchments that increases lake storage for all three future periods for both A2 and B2 emission scenarios

Overall finding on impacts of climate change on the Lake Tana water balance indicates that lake water storage increases for both A2 and B2 emission scenarios. The major difference among the emission scenarios is extensively described at [25] and these differences lead to different impacts on lake water balance of Lake Tana as presented in Table 1.

Recently, a number of studies report on a comparison of SRES scenarios and RCPs [26] [27]. The study of [26] provided probabilistic projection of climate for both SRES scenarios and RCPs. Their study revealed that global mean temperature projections by the end of the $21^{\text {st }}$ century for the RCPs are very similar to those of their closest SRES counterparts. Similarly, [28] simulated changes in global mean temperature by the SRES scenarios (CMIP3) and RCPs (CMIP5). They have concluded that similarity of the projected precipitation change in both models is reassuring and that results for RCP and SRES are comparable. Whereas model mean patterns of precipitation and temperature are remarkably similar in SRES scenarios and RCPs; [27] showed large variation in outputs from eight RCPs by the Coordinated Regional Climate Downscaling Experiment (CORDEX) initiative for equal climate change scenarios.

In this study, three SRES emission scenarios are applied that have equal probability of occurrence [29]. Since such unchanged probability is questionable, this causes uncertainty to projected climate changes. In addition, downscaled SDSM outputs for these scenarios for temperature and, in particular, precipitation must be associated with a certain level of uncertainty. Consequently, findings on increase of Lake Tana water storage for future periods should be interpreted with care and only serve as an indication to the likely impact of climate change on Lake Tana water balance.

Future studies should consider the entire range of emission scenarios and should aim at applying outputs from more RCM models to solve the water balance of Lake Tana following the approach in this study.

\section{References}

[1] Hulme, M., Doherty, R., Ngara, T., New, M. and Lister, D. (2001) African Climate Change: 1900-2100. Climate Research, 17, 145-168. http://dx.doi.org/10.3354/cr017145

[2] Beyene, T., Lettenmaier, D.P. and Kabat, P. (2010) Hydrologic Impacts of Climate Change on the Nile River Basin: Implications of the 2007 IPCC Scenarios. Climatic Change, 100, 433-461. http://dx.doi.org/10.1007/s10584-009-9693-0

[3] Kim, U. and Kaluarachchi, J.J. (2009) Climate Change Impacts on Water Resources in the Upper Blue Nile River Basin, Ethiopia1. Journal of the American Water Resources Association, 45, 1361-1378. http://dx.doi.org/10.1111/j.1752-1688.2009.00369.x

[4] Taye, M.T., Ntegeka, V., Ogiramoi, N.P. and Willems, P. (2013) Assessment of Climate Change Impact on Hydrological Extremes in Two Source Regions of the Nile River Basin. Hydrology and Earth System Sciences, 15, 209-222. http://dx.doi.org/10.5194/hess-15-209-2011

[5] SMHI. (2006) The HBV Model. http://www.smhi.se/forskning/forskningsomraden/hydrologi/hbv-1.1566

[6] Rientjes, T.H.M., Perera, B.U.J., Haile, A.T., Reggiani, P. and Muthuwatta, L.P. (2011a) Regionalization for Lake 
Level Simulation: The Case of Lake Tana in the Upper Blue Nile, Ethiopia. Hydrology and Earth System Sciences, 15, 1167-1183. http://dx.doi.org/10.5194/hess-15-1167-2011

[7] Rientjes, T.H.M., Perera, J.B.U., Haile, A.T. and Gieske, A.S.M. (2011b) Hydrological Balance of Lake Tana, Upper Blue Nile Basin, Ethiopia. In: Melesse, A.M., Ed., Nile River Basin: Hydrology, Climate and Water Use, Springer, Dordrecht, 69-89, 419 p. http://dx.doi.org/10.1007/978-94-007-0689-7_3

[8] Chebud, Y.A. and Melesse, A.M. (2009) Modelling Lake Stage and Water Balance of Lake Tana, Ethiopia. Hydrological Processes, 23, 3534-3544. http://dx.doi.org/10.1002/hyp.7416

[9] Subramanya (2008) Engineering Hydrology. 7 West Patel Nagar. Tata McGraw-Hill, New Delhi.

[10] Wilby, R.L. and Dawson, C.W. (2008) SDSM 4.2-A Decision Support Tool for the Assessment of Regional Climate Change Impacts. Statistical DownScaling Model SDSM Version 4.2.

[11] Canada, E. (2012) Regional Climate Models. http://www.cics.uvic.ca/scenarios/sdsm/select.cgi

[12] Wilby, R.L., Dawson, C.W. and Barrow, E.M. (2002) SDSM-A Decision Support Tool for the Assessment of Regional Climate Change Impacts. Environmental Modelling \& Software, 17, 147-159. http://dx.doi.org/10.1016/S1364-8152(01)00060-3

[13] Ortseifen, C. (1996) Afifi, A.A. and Clark, V.: Computer-Aided Multivariate Analysis. Third Edition. Chapman \& Hall, 1996. 480 pp. £ 39.95. ISBN 0-412-73060 X. Biometrical Journal, 39, 875-876. http://dx.doi.org/10.1002/bimj.4710390716

[14] Hessami, M., Gachon, P., Ouarda, T.B.M.J. and St-Hilaire, A. (2008) Automated Regression-Based Statistical Downscaling Tool. Environmental Modelling \& Software, 23, 813-834. http://dx.doi.org/10.1016/j.envsoft.2007.10.004

[15] Abdo, K.S., Fiseha, B.M., Rientjes, T.H.M., Gieske, A.S.M. and Haile, A.T. (2009) Assessment of Climate Change Impacts on the Hydrology of Gilgel Abay Catchment in Lake Tana Basin, Ethiopia. Hydrological Processes, 23, 36613669. http://dx.doi.org/10.1002/hyp.7363

[16] Vrac, M., Drobinski, P., Merlo, A., Herrmann, M., Lavaysse, C., Li, L. and Somot, S. (2012) Dynamical and Statistical Downscaling of the French Mediterranean Climate: Uncertainty Assessment. Natural Hazards and Earth System Sciences, 12, 2769-2784. http://dx.doi.org/10.5194/nhess-12-2769-2012

[17] Rudolf, B. and Rubel, F. (2005) Global Precipitation. In: Hantel, M., Ed., Observed Global Climate, New Series, Landolt-Bornstein: Numerical Data and Functional Relationships in Science and Technology, Group 5: Geophysics, 6(A), Springer, Berlin, 11.1-11.53.

[18] Haile, A.T., Rientjes, T., Gieske, A. and Gebremichael, M. (2009) Rainfall Variability over Mountainous and Adjacent Lake Areas: The Case of Lake Tana Basin at the Source of the Blue Nile River. Journal of Applied Meteorology and Climatology, 48, 1696-1717. http://dx.doi.org/10.1175/2009JAMC2092.1

[19] Hargreaves, G.H. and Samani, Z.A. (1982) Estimating Potential Evapotranspiration. Journal of the Irrigation \& Drainage Division-ASCE, 108, 225-230.

[20] SMHI (2006) The HBV Model-Its Structure and Applications. http://www.smhi.se/en/publications/hydrological-ensemble-forecasts-hydrologiska-ensembleprognoser-1.6763

[21] Gagnon, S., Singh, B., Rousselle, J. and Roy, L. (2005) An Application of the Statistical DownScaling Model (SDSM) to Simulate Climatic Data for Streamflow Modelling in Québec. Canadian Water Resources Journal, 30, 297-314. http://dx.doi.org/10.4296/cwrj3004297

[22] Beyene, T., Lettenmaier, D.P. and Kaba, P. (2010) Hydrologic Impacts of Climate Change on the Nile River Basin: Implications of the 2007 IPCC Scenarios. Climatic Change, 100, 433-461.

[23] Sokolov, A.P., Stone, P.H., Forest, C.E., Prinn, R.G., Sarofim, M.C., Webster, M., Paltsev, S., Schlosser, C.A., Kicklighter, D., Dutkiewicz, S., Reilly, J., Wang, C., Felzer, B., Melillo, J. and Jacoby, H.D. (2009) Probabilistic Forecast for 21st Century Climate Based on Uncertainties in Emissions (without Policy) and climate Parameters. Journal of Climate, 22, 5175-5204. http://dx.doi.org/10.1175/2009JCLI2863.1

[24] IPCC (Intergovernmental Panel on Climate Change) (2012) Managing the Risks of Extreme Events and Disasters to Advance Climate Change Adaptation. A Special Report of Working Groups I and II of the Intergovernmental Panel on Climate Change. Field CB, Press, Camb., UK and NY, USA, 582.

[25] IPCC (Intergovernmental Panel on Climate Change) (2000) Comments on the SRES Final Draft (Open Archive). Technical Support Unit of IPCC Working Group III, Netherlands Environmental Assessment Agency, Bilthoven.

[26] Rogelj, J., Meinshausen, M. and Knutti, R. (2012) Global Warming under Old and New Scenarios Using IPCC Climate Sensitivity Range Estimates. Nature Climate Change, 2, 248-253. http://dx.doi.org/10.1038/nclimate1385

[27] Haile, T.A. and Rientjes, T.H.M. (2015) Evaluation of regional Climate Model Simulations of Rainfall over the Upper Blue Nile Basin. Atmospheric Research, 161-162, 57-64. http://dx.doi.org/10.1016/j.atmosres.2015.03.013 
[28] Knutti, R. and Sedlacek, J. (2013) Robustness and Uncertainties in the New CMIP5 Climate Model Projections. Nature Climate Change, 3, 369-373. http://dx.doi.org/10.1038/nclimate1716

[29] Ward, J.D., Werner, A.D., Nel, W.P. and Beecham, S. (2011) The Influence of Constrained Fossil Fuel Emissions Scenarios on Climate and Water Resource Projections. Hydrology and Earth System Sciences, 15, 1879-1893.

http://dx.doi.org/10.5194/hess-15-1879-2011 